\title{
Organizational and methodological support for Ukrainian coal enterprises marketing activity improvement
}

\author{
Aleksy Kwilinski ${ }^{1}$, Yuliya Zaloznova ${ }^{2}$, Nataliia Trushkina ${ }^{3, *}$, and Natalia Rynkevych $^{4}$ \\ ${ }^{1}$ The London Academy of Science and Business, W1U 6TU, London, Baker Str., 120, England \\ ${ }^{2}$ Institute of Industrial Economics of NAS of Ukraine, 03057, Kyiv, Mary Kapnist Str., 2, Ukraine \\ ${ }^{3}$ Institute of Industrial Economics of NAS of Ukraine, 03057, Kyiv, Mary Kapnist Str., 2, Ukraine \\ ${ }^{4}$ Prydniprovsk State Academy of Civil Engineering and Architecture, 49600, Dnipro, \\ Chernyshevskoho St., 24a, Ukraine
}

\begin{abstract}
The tendencies of marketing policy development in some world's mining countries in the light of global transformational changes are considered. The factors influencing the marketing activity of Ukrainian coal mining enterprises are identified. The volumes and structure of coal consumption in Ukraine are analyzed with a purpose to identify trends of demand volatility and specifics of logistics services for different consumer categories. It is substantiated the expediency of marketing networks formation as a form of partnership relations between different counterparties in the coal market. It is proposed the mechanism of realization of public-private partnership in the management of coalmining enterprises marketing activity based on syndicate form of incorporation. It is improved the methodological approach, which by use of the hierarchy analysis method allows selecting the optimal direction of enterprises organizational culture transformation based on defining 12 the most important criteria and their systematization into 4 groups. An integrated assessment of the level of organizational culture development of coal mining enterprises is made using economic and mathematical tools.
\end{abstract}

\section{Introduction}

Nowadays, in the condition of changing economic development, coal mining companies have a problem finding the most efficient ways to sell coal. This is due to insufficient adaptation of existing systems for managing the marketing activities of enterprises to the constant changes in the institutional environment and fluctuations in consumer demand, as well as a significant dependence on the multiplicity of counterparties and consumers, the impact of factors (delayed payment for shipped products, insufficient financial-investment resources, unstable market, etc.). These disadvantages cause an increase in the cost of these enterprises. Taking into account all listed above, it is advisable to carry out further scientific research in the direction of developing organizational and methodological support

*Corresponding author: nata_tru@ukr.net 
for improving the marketing activities of coal mining enterprises that should meet modern requirements of management. This is the purpose of this article.

\section{Methods}

\subsection{Global trends in the development of coal companies' marketing policy}

Foreign researches [1-11] show that coal remains a strategically important resource for energy independence in most countries of the world. According to the International Energy Agency, the global trends in the organization of marketing activity in many coal mining countries around the world are identified, including the following:

- reduction of global coal production in 2015-2017 of $2.4 \%$ due to the reduction of thermal coal of $2.4 \%$ (from 5819.7 to 5677.9 million tons), coking coal - of $4.4 \%$ (from 1087.6 to 1039.9 million tons). This is caused by the decrease in coal production in the US - of $13.7 \%$, Poland - of $6.5 \%$, China - of $5.3 \%$, Germany - of $5.2 \%$, Australia - of $2.4 \%$, Kazakhstan - of $1.2 \%$. At that, coal production in India increased by $6.8 \%$, in Indonesia - by $7.2 \%$, South Africa - by $0.7 \%$, in other countries - by $4.6 \%$. The leaders in coal production in 2017 were: China (share of global coal production - $44.7 \%$ ), India (9.7 \%), USA (9.3\%), Australia (6.6\%), Indonesia (6.5\%);

- coal products global exports increase of 5\%. Coal exports in 2017 were almost $28 \%$ higher than in 2010, and have doubled compared to 2000. The world's exports of coking coal increased by $7.2 \%$ in $2015-2017$, or from 305.3 to 327.2 million tons. Indonesia and Australia were the leading coal exporters. They exported correspondingly $28.5 \%$ and $27.7 \%$ of world coal export. According to the analysis, the export of coking coal from the USA increased in 2017 by $20.1 \%$ or from 41.7 to 50.1 million tons in 2015 ; from Canada by $3.6 \%$ or from 28 to 29 million tons; from Mongolia - by $105.6 \%$, or from 12.5 to 25.7 million tons;

- an increase in coal global import by $6.2 \%$ due to an increase in China of $32.8 \%$, in Malaysia of $23.5 \%$, in Turkey of $12.6 \%$, in North Korea of $10.6 \%$, in Taiwan of $3.7 \%$. However, in some countries, the import of coal products declined: in the Netherlands - by $29.4 \%$, in Germany - by $11.9 \%$, in India - by $1.8 \%$, in Japan - by $1 \%$. The leading importers of coal in 2017 were: China (19.5\% of world import), India (15\%), Japan (13.5\%), South Korea (10.7\%), Taiwan (4.8\%);

- the negative balance of export-import transactions in the sale of coal (except 2016, when export exceeded import by $0.7 \%$ );

- coal imports exceed exports of 1.01 times in 2017, and in 2015 it was insignificant (except 2016);

- reduction of global thermal coal consumption in 2015-2017 of $1.3 \%$. In China, the reduction was $3 \%$, in the US - $11.5 \%$, in Japan - $1.5 \%$. However, in some countries, coal consumption increased in 2017 compared to 2015: in India - by $8.1 \%$, in South Africa - by $3.5 \%$, in South Korea - by $13.6 \%$, in Indonesia - by $11.8 \%$, in Kazakhstan - by $4.8 \%$, in Poland - by $4.4 \%$, in Taiwan - by $6.5 \%$, in Australia - by $18.8 \%$. The leading consumers of thermal coal in the world in 2017 were: China (52.8\% of global coal consumption), India (14\%), the United States (9.7\%), South Africa (3.2 \%), Japan (2.5\%).

A characteristic feature of global demand is that in Europe, consumption decreases every year, and, conversely, in Asia, demand for coking coal increases. Thus, the game of major players in the global coal market is provided by a sophisticated, yet reliable and flexible system of commodity logistics and marketing support for companies' sales activity. 


\subsection{Influence of factors on the organization of Ukraine's coal-mining enterprises' marketing activity}

It is proved that the organization of marketing activity is influenced by various factors, which are conditionally organized into two groups:

$$
F=\left\{\begin{array}{l}
F_{1}\left(f_{11}, f_{12}, f_{13}, f_{14}, f_{15}, f_{16}, f_{17}\right) \\
F_{2}\left(f_{21}, f_{22}, f_{23}, f_{24}, f_{25}\right)
\end{array}\right.
$$

where $F_{1}$ are the factors of the external environment: $f_{11}$ - political (unstable political situation in the country); $f_{12}$ - institutional (imperfect legal regulation of marketing, commercial and exchange activities; lack of a national coal exchange); $f_{13}$ - financial (constant changes in exchange rate fluctuations); $f_{14}$ - market (constant coal market fluctuations; coal products demand volatility); $f_{15}$ - economic (high level of prices for imported coal compared to Ukrainian; increase in the ratio of import and export coal products); $f_{16}$ - information (lack of electronic coal trading platform); $f_{17}$-environmental (negative impact on the environment caused by the violation of products transportation conditions); $F_{2}$ - internal factors: $f_{21}$ - marketing (insufficient consideration of customer needs servicing different categories of coal products consumers; the imperfection of enterprises' contract activity); $f_{22}$ - technological (difficult conditions of coal production; weak use of innovative technologies); $f_{23}$ - financial and economic (delayed payment for shipped coal; insufficient investment and financial resources; increase in coal production loss ratio); $f_{24}$-transport (late delivery of goods because of breakage or unforeseen standing idle of vehicles; unavailability of cargo in due time; loss of cargo due to unfavorable transportation conditions); $f_{25}$-information (insufficient use of digital technologies and electronic platforms to manage customer relations).

The mentioned above factors are confirmed by the results of the statistical analysis. Thus, the volume of coal consumption in Ukraine in 2007-2018 decreased by $36.1 \%$, and production - by $55.3 \%$. At the same time, there is a tendency of coal's deficit increase (mainly coking and anthracite): in 2007 the consumption exceeded coal production by $20.5 \%$, whereas in 2018 - by $72.6 \%$ (Table 1 ).

Table 1. Dynamics of coal production and consumption in Ukraine, mln. t.

\begin{tabular}{|l|c|c|c|c|c|c|c|}
\hline \multirow{2}{*}{\multicolumn{1}{|c|}{ Indicators }} & \multicolumn{7}{|c|}{ Years } \\
\cline { 2 - 8 } & 2007 & 2009 & 2012 & 2014 & 2015 & 2017 & 2018 \\
\hline $\begin{array}{l}\text { Volume of coal } \\
\text { consumption }\end{array}$ & 71.0 & 63.0 & 73.3 & 53.9 & 45.3 & 42.7 & 45.4 \\
\hline $\begin{array}{l}\text { Volume of coal } \\
\text { production }\end{array}$ & 58.9 & 55.0 & 65.7 & 45.9 & 29.9 & 24.2 & 26.3 \\
\hline Ratio, times & 1.21 & 1.15 & 1.12 & 1.17 & 1.52 & 1.76 & 1.73 \\
\hline
\end{tabular}

Compiled according to the statistics data of the State Statistics Service of Ukraine.

According to informational - analytical materials of the Ministry of Energy and Environmental Protection of Ukraine, in 2010-2018 total coal production decreased by $55.5 \%$ due to a significant decrease in coking coal production of $75.8 \%$ and thermal coal of $45.9 \%$. The share of coking coal production in the national volume decreased from 32.1 to $17.5 \%$, or by $14.6 \%$, and of thermal coal, respectively, increased from 
67.9 to $82.5 \%$. It should be noted that in $2010-2014$ there was a tendency when the amount of coal production exceeded consumption, and since 2015, on the contrary, consumption was higher than the volume of production. Calculations show that in 2010, the ratio of coal production and consumption was 1.11 times, and in 2018, consumption exceeded the production volume by 1.32 times. According to the analysis, in 20102018 , the total amount of coal consumption decreased by $34.8 \%$, including consumption by thermal power plants - by $19.3 \%$. The share of coal consumption by thermal power plants increased by $11.5 \%$, or from 47.9 to $59.4 \%$ of the total volume in Ukraine (Table 2).

Table 2. Dynamics of coal production and consumption in Ukraine.

\begin{tabular}{|c|c|c|c|c|c|}
\hline \multirow[b]{2}{*}{ Years } & \multirow{2}{*}{$\begin{array}{c}\text { The total } \\
\text { amount of } \\
\text { production, } \\
\text { thousand } \\
\text { tons }\end{array}$} & \multicolumn{2}{|c|}{ Including } & \multirow{2}{*}{$\begin{array}{l}\text { The total } \\
\text { volume of } \\
\text { consumption, } \\
\text { thousand tons }\end{array}$} & \multirow{2}{*}{$\begin{array}{l}\text { Including } \\
\text { thermal } \\
\text { power plants, } \\
\text { thousand tons }\end{array}$} \\
\hline & & $\begin{array}{c}\text { coking coal, } \\
\text { thousand } \\
\text { tons }\end{array}$ & $\begin{array}{l}\text { thermal coal, } \\
\text { thousand tons }\end{array}$ & & \\
\hline 2010 & 75188.0 & 24150.1 & 51037.9 & 67917.4 & 32538.7 \\
\hline 2011 & 81843.6 & 24843.1 & 57000.5 & 51803.1 & 27276.1 \\
\hline 2012 & 85946.0 & 24823.5 & 61122.5 & 61207.1 & 32227.6 \\
\hline 2013 & 83697.5 & 23724.5 & 59973.0 & 71490.0 & 37641.9 \\
\hline 2014 & 64995.3 & 16139.3 & 48856.0 & 59943.2 & 31562.1 \\
\hline 2015 & 39744.7 & 8325.1 & 31419.6 & 54388.9 & 28637.6 \\
\hline 2016 & 40864.1 & 8361.4 & 32502.7 & 59518.7 & 31338.6 \\
\hline 2017 & 34916.1 & 6807.3 & 28108.8 & 47121.9 & 24811.3 \\
\hline 2018 & 33438.3 & 5836.0 & 27602.3 & 44261.6 & 26272.1 \\
\hline
\end{tabular}

Compiled and calculated according to information-analytical materials of the Ministry of Energy and Environment of Ukraine.

State coal enterprises thermal coal production decreased by $25 \%$ in $2015-2018$ (from 4.8 to 3.6 million tons), production for the private sector decreased by $10.2 \%$ (from 26.6 to 23.9 million tons). The volume of coking coal production by state-owned enterprises decreased by $70 \%$ (from 2 to 0.6 million tons), by private enterprises - by $17.5 \%$ (from 6.3 to 5.2 million tons).

In 2015-2018, the thermal power plants and combined heat and power plants consumption of gas coal ranks increased by $8.3 \%$ (from 19.2 to 20.8 million tons), while anthracite coal consumption, on the contrary, decreased by $42.6 \%$ (from 9.4 to 5.4 million tons). This is due to the modernization of thermal power plants and combined heat and power plants for the use of coal gas ranks. In 2007-2018 the level of payments of energy generating companies for coal output decreased by $5.5 \%$ - from $98.9 \%$ to $93.4 \%$. For the researched period, there was a loss of coal production in the public sector. In 2007, the index was $33.2 \%$, in $2014-41.1 \%$, in $2016-44.4 \%$, in 2018 $22.7 \%$. It is worth noting that every year the ratio of budget subsidies to losses per 1 ton of coal production by state mines reduces. Thus, in 2012 the value of this index was 1.02 times. But since 2013 the losses exceeded the budget subsidies per 1 ton of coal production: in 2014 the value of such excess was 1.18 times, in $2015-2.65$ times, in 2016 - 1.82 times, in $2018-1.15$ times.

Currently, the characteristic of coal industry development is a significant reduction in the volume of coal exports and, consequently, an increase in its imports (usually coking coal and anthracite). According to the State Statistics Service of Ukraine, the volume of coal exports in $2007-2017$ decreased by $83.8 \%$ (from 3.7 to 0.6 million tons) and the 
volume of coal imports increased by $50 \%$ (from 13.2 to 21,4 million tons). At the same time, there is a tendency when the volume of coal imports exceeds exports. In 2007 the value of this indicator was 3.6 times, while in 2016 - 31.2 times, and in 2017 - 33 times. In 2018 , the was no export of coal products at all. The balance of coal exports and imports was negative.

It should be noted that the increase in coal supply, which is not provided in the energy balance of Ukraine, leads to an imbalance in the qualitative composition and outflow of financial resources from the state budget for imported coal purchase due to the high level of prices (taking into account transportation costs). Thus, if the average price of 1 ton of coal of Ukrainian production in 2017 was 62 USD. In 2015 - 51, in 2016 - 48), then the Polish 99, Canadian - 106, Australian - 109, American - 112 US \$. According to the IHS Market company, the price of thermal coal on the terms of CIF ports Amsterdam, Rotterdam, Antwerp was 84.5 \$ in 2017 and 91.7 \$ in 2018 .

Thus, in the result of the study, it is found that the statistical data provided in the information and analytical materials of the State Statistics Service of Ukraine and the Ministry of Energy and Environmental Protection of Ukraine significantly differ. This complicates the assessment of the main performance indicators of coal enterprises and affects the formation of strategies, programs and energy balance of the state. Therefore, the abovementioned state authorities need to cooperate while the preparation of reference, informational and statistical documentation, which will permit to avoid numerous divergence in statistics and provide reasoned and scientifically based conclusions and recommendations for improving the organization of coal industry marketing activity.

\subsection{Volumes and structure of consumption analysis in Ukraine}

Based on the analysis of the energy balance of Ukraine, it is established that the total amount of coal consumption in Ukraine decreased by $35.1 \%$ in 2012-2018. It is connected with a volume decrease of coal to fuel and energy conversion by $36.8 \%$ (from 67286 to 42536 thousand tons) resulted from the decrease in coal consumption by power plants of $37 \%$ (from 37495 to 23632 thousand tons) and combined heat and power plants - of $24,2 \%$ (from 1269 to 962 thousand tons). Because of the significant reduction in metallurgical industry production, the consumption of coal for coke production decreased by $40.7 \%$ (from 26489 to 15710 thousand tons). For the researched period, coal consumption by the industry decreased by $18.6 \%$ (from 3752 to 3056 thousand tons) due to decrease in consumption of ferrous metallurgy of $28.3 \%$ (from 2466 to 1769 thousand tons) and mineral raw materials processing for various industries of $8.6 \%$ (from 1110 to 1015 thousand tons). The volume of coal consumption by rail transport decreased in 2018 compared to 2012 by $59.1 \%$ (from 22 to 9 thousand tons).

Whereas, according to the State Statistics Service of Ukraine, the total amount of coal consumption in Ukraine decreased by $36.2 \%$ in 2007-2018. This was owing to the reduction in the use of coal for non-energy purposes of $86.7 \%$ (from 1.5 to 0.2 million tons), to the conversion of coal to other fuels and energy of $35.4 \%$ (from 64.2 to 41.5 million tons) and for final consumption - of $32.1 \%$ (from 5.3 million to 3.6 million tons).

According to the research, the Ministry of Energy and the Environment of Ukraine does not publish newsletters about the volume and structure of coal consumption by different groups of consumers, while the State Statistics Service of Ukraine only provides information on the structure of coal consumption by such statistical areas as coal conversion into other fuels and energy, final consumption and non-energy purposes. It 
should be noted that statistical materials do not correlate with each other and do not take into account the process of movement of commercial coal products from producers to consumers. Only the energy balance of Ukraine provides information on coal consumption. However, statistics in the balance are provided only by major economic activities, not taking into account the specificity of large, medium and small wholesale supplies of coal products. Besides, it can be approved that the energy balance has inaccurate information since it characterizes the development of the public sector of the coal industry and does not contain statistics on the consumption of coal by industrial consumers of private ownership. All this leads to insufficient monitoring of the current state of marketing activity organization of coal enterprises. Therefore, the abovementioned institutions need to work together to improve the energy balance and develop a common methodology for assessing the level and quality of service to different customer groups of coal products.

\section{Results and discussion}

\subsection{Creation of marketing networks as effective models of coal market participants' partnership}

Based on the specificity of the coal enterprises' marketing activity organization [12-16], it is substantiated the feasibility of marketing networks forming as forms of partnership relations between different counterparties in the coal market.

The first model (direct distribution channel) supposes an agreement of coal-mining enterprises with thermal power plants based on contracts for the coal products supply. There is a material flow in the form of coal supplies from coal-mining enterprises to the thermal power plants, and there is a financial flow in the form of payment for the coal shipped from thermal power plants to the coal-mining enterprise. In a process, thermal power plants should control the supply and set a price for coal products, which is considered as an investment resource in the development of coal mining enterprises. An advantage of such a model of marketing network is the optimal level of coal prices at the expense of direct deliveries organization.

The second model involves the formation of an electronic exchange platform, the main purpose of which is to provide services for the centralized execution of exchange contracts through the coal products electronic trading. Setting the best price based on a real balance of coal supply and demand on the market is a key benefit of this model.

The third marketing network model provides the creation of a syndicate based on the agreement between the coal mining enterprises of different forms of ownership to organize, control and regulate joint marketing activity based on public-private partnership. This legal form of organization is stipulated by the current legislation of Ukraine, which states the possibility of merging enterprises on a sectoral basis. Revenue between union members should be distributed under the terms of the joint venture agreement. Within the public-private partnership, the syndicate has the function of marketing activity management, which includes forecasting and planning (determining the required volume of coal production based on demand; pricing policy; elaboration of the coal mining enterprises development strategy); organization of marketing processes, control, and regulation of their timely realization. The practical implementation of this form will facilitate timely response to changes in demand for coal products; sharing risks between public and private coal enterprises as well as their minimization; organization of continuous supply and provision of guaranteed sale channels of coal products for state coal-mining enterprises. 


\subsection{Determination of the optimal direction of coal enterprises organizational culture transformation}

One of the directions of organizational and methodological support for improving the coal mining enterprises' marketing activity is the organizational culture modernization in the context of corporate social responsibility. In June-August 2019, on the basis of the expert survey, it was conducted an empirical study of the organizational culture of enterprises of different types of economic activity (including the coal industry) [17-18].

It is established that the organizational culture of coal enterprises is characterized by several distinctions:

- mostly top management influences the formation of organizational culture $(80 \%$ of respondents);

- organizational culture, as a rule, was formed spontaneously (80\%), and the remaining experts $(20 \%)$ stated that it was organized by coal company management;

- organizational culture of companies is not effective $(60 \%)$ and has several disadvantages: enterprise's employees don't understand, what "client-oriented approach to the formation of organizational culture" is $(40 \%)$; inability to support marketing communications with the clients (40\%); an absence of a commonly accepted definition of customer orientation $(20 \%)$; organizational culture is built not around customer needs $(20 \%)$; the organization is focused on sales and profit, not on consumers, thus, the company is not customer-focused (20\%);

- organizational culture influences the financial results of enterprises: totally $(20 \%$ of respondents) or partially $(60 \%)$;

- successful organizational culture of enterprises results in cost reduction and expenditures savings $(60 \%)$.

As a result of research, a methodical approach is offered to choose an optimal direction of enterprises' organizational culture transformation, the essence of which is to determine the most important evaluation criteria that are organized into four groups:

$$
K=K_{1}\left(k_{11}, k_{12}, k_{13}\right) \cup K_{2}\left(k_{21}, k_{22}, k_{23}\right) \cup K_{3}\left(k_{31}, k_{32}, k_{33}\right) \cup K_{4}\left(k_{41}, k_{42}, k_{43}\right)
$$

where $K_{1}$ - adaptability (ability to adapt): the ability to organizational change $\left(k_{11}\right)$; customer focus $\left(k_{12}\right)$; organizational training $\left(k_{13}\right) ; K_{2}$ - mission: strategic direction and intentions $\left(k_{21}\right)$; goal setting $\left(k_{22}\right)$; vision $\left(k_{23}\right) ; K_{3}$ - consistency (coherence): coordination and integration $\left(k_{31}\right)$; ability to consensus $\left(k_{32}\right)$; sharing of key values $\left(k_{33}\right)$; $K_{4}$-involvement: development of abilities $\left(k_{41}\right)$; teamwork orientation $\left(k_{42}\right)$; responsibility and authority $\left(k_{43}\right)$.

The hierarchy analysis method proved that the best way to modernize the organizational culture of coal enterprises is to improve the skills of employees because it has the highest efficiency compared to other directions.

This is also confirmed by the results of an expert survey conducted at Ukrainian coal enterprises. It was found that the surveyed enterprises required a partial $(80 \%$ of respondents) transformation of organizational culture. According to the survey, the organizational culture modernization should involve employees' skills improvement (60\%) and eliminating the bureaucratic component while business processes organization at the enterprises $(20 \%)$. However, despite the fact that customer focus is a key direction of enterprise activity, only $20 \%$ of surveyed coal industry experts indicated the advisability of customer relations management system transformation.

Using the methods of D. Denison [19], G. Hofstede [20], K. Cameron, and R. Quinn [21], an advanced method of organizational culture quantitative assessment is proposed. An 
integrated assessment of organizational culture showed that surveyed enterprises have a low level of organizational culture development since the value is 0.469 , i.e. it is within the limits of $0.26-0.50$ (Table 3 ).

Table 3. Coal enterprises organizational culture assessment.

\begin{tabular}{|c|c|}
\hline \multicolumn{2}{|c|}{ Characteristics / organizational culture indicators / average value } \\
\hline$K_{1}(0,408)$ & $K_{3}(0,407)$ \\
\hline$k_{11}(0,313)$ & $k_{31}(0,438)$ \\
\hline$k_{12}(0,438)$ & $k_{32}(0,376)$ \\
\hline$k_{13}(0,688)$ & $k_{33}(0,407)$ \\
\hline$K_{2}(0,511)$ & $K_{4}(0,479)$ \\
\hline$k_{21}(0,469)$ & $k_{41}(0,250)$ \\
\hline$k_{22}(0,563)$ & $k_{42}(0,469)$ \\
\hline$k_{23}(0,500)$ & $k_{43}(0,719)$ \\
\hline
\end{tabular}

Compiled and calculated by the authors according to the survey results.

\section{Conclusions}

The conducted statistical analysis shows that the Ukrainian coal enterprises marketing activity organization is influenced by various factors, which are systematized into two groups: external institutional environment factors (political, institutional, financial, market, economic, informational) and internal (financial and economic, marketing, technological, informational).

An analysis of coal consumption volume and structure in Ukraine shows the regularity of unstable demand for coal products of different customer categories. It is advisable to use three possible marketing network models for an effective application of the network approach to the coal-mining enterprises marketing activity organization: direct coal supply from a coal-mining enterprise to a thermal power plant; electronic exchange platform for coal products sale; a syndicate form of a partnership of coal companies with the purpose to organize, control and regulate joint marketing activity.

An integrated assessment of coal industry enterprises' organizational culture is carried out, obtained results show low level and insufficiently high quality of their organizational culture.

It is offered a methodical approach for choosing an optimal scenario of coal mining enterprises' organizational culture development that permits defining the most important criteria and systematizing them in groups using the hierarchy analysis method. The approbation of this approach showed that the first-priority way of coal enterprises' organizational culture transformation is to improve the personnel' skills. It should be emphasized that the surveyed enterprises do not pay attention to such an extremely important direction of organizational culture modernization, as digital technologies use that would allow optimizing business processes in coal companies.

\section{References}

1. Rehbach, S., Samek, R. (2015). Downsizing the USA coal industry: Can a slow-motion train wreck be avoided? Metal \& Mining Practice. New York: McKinsey \& Company, $1-10$ 
2. Huang, H. (2018). China Coal Mining and Coal Washing Practices. $1^{\text {st }}$ ed. Shenzhen: Dazhong Publishing House

3. Kretschmann, J., Efremenkov, A.B., Khoreshok, A.A. (2017). From Mining to PostMining: The Sustainable Development Strategy of the German Hard Coal Mining Industry. Ecology and safety in the technosphere: current problems and solutions. IOP Conf. Series: Earth and Environmental Science, 50, 1-9. DOI: 10.1088/17551315/50/1/012024

4. Widuto, A. (2019). EU support for coal regions. Brussel: European Parliamentary Research Service. URL: https://www.europarl.europa.eu/RegData/etudes/BRIE/ 2019/642217/EPRS_BRI(2019)642217_EN.pdf

5. Oei, P., Brauers, H., Herpich, Ph. (2019). Lessons from Germany's hard coal mining phase-out: policies and transition from 1950 to 2018. Climate Policy, 11, 1-17. DOI: 10.1080/14693062.2019.1688636

6. Blaschke, W., Baic, J. (2016). Coal Mining and Coal Preparation in Poland. Gzasopismo Techniczne, 40-45

7. Michalak, A. (2017). Specific risk in hard coal mining industry in Poland. Forum Sciential Oeconomia, 5(1), 71-77. DOI: 10.23762/fso_vol5no1_6

8. Pająk, K., Kvilinskyi, O., Fasiecka, O., Miśkiewicz, R. (2017). Energy security in regional policy in Wielkopolska region of Poland. Economics and Environment, 2(61), 122-138

9. Szpor, A., Ziolkowska, K. (2018). The Transformation of the Polish Coal Sector. GSI Report. The International Institute for Sustainable Development

10. Karpenko, L., Serbov, M., Kwilinski, A., Makedon, V., Drobyazko, S. (2018). Methodological platform of the control mechanism with the energy saving technologies. Academy of Strategic Management Journal, 17(5), 1-7

11. Dzwigoł, H., Dzwigoł-Barosz, M., Zhyvko, Z., Miskiewicz, R., Pushak, H. (2019). Evaluation of the energy security as a component of national security of the country. Journal of Security and Sustainability Issues, 8(3), 307-317. DOI: 10.9770/ jssi.2019.8.3(2)

12. Amosha, O., Zaloznova, Yu., Cherevatskyi, D., Atabekov, O. (2013). The Ukrainian Coalsurplusand the Ways of Copingwithit. Platzbestimmung Osteuropasindersozioökonomischen Globalisierung. Berlin: Forschungsinstitut der Internationalen Wissenschaftlichen Vereinigung Weltwirtschaft und Weltpolitik, 110-115

13. Amosha, A., Zaloznova, Yu., Cherevatskyi, D. (2017). Ugolnaya promyshlenost $i$ gibridnaya ekonomika [Coal mining industry and gibrid economics]. Kyiv: Institute of Industrial Economics of NAS of Ukraine (in Russian)

14. Zaloznova, Yu., Trushkina, N. (2017). Methodical support of improving the organization of marketing activity of the coal-mining enterprises of Ukraine. Baltic Journal of Economic Studies, 3(1), pp. 36-44

15. Amosha O., Zaloznova Yu., Cherevatskyi D. (2018). Regimeology of coal markets. Naukoviyi Visnyk NHU, 2018, № 2 (164), pp. 148-154. DOI: 10.29202/nvngu/2018$2 / 20$

16. Zaloznova Yu., Trushkina N. (2018). Mechanism for the implementation of publicprivate partnership during management of marketing activity of enterprises in the coalmining industry. Research Papers in Economics and Finance, 3(1), pp. 27-35. DOI: 10.18559/ref.2018.1.3

17. Rynkevych, N.S. (2019). Organizational culture of enterprises: challenges, threats and trends. Economic Herald of the Donbas, 57, 3, pp. 123-136. DOI: 10.12958/18173772-2019-3(57)-123-136 (in Ukrainian)

18. Trushkina, N.V., Rynkevych, N.S. (2019). Methodical approach to evaluation the level of development of organizational culture of enterprises. Black Sea Economic Studies, 
48-2, pp. 112-118. DOI: 10.32843/bses.48-51 (in Ukrainian)

19. Denison, D.R. (1990). Corporate culture and organizational effectiveness. New York: John Wiley \& Sons

20. Hofstede, G. (2011). Dimensionalizing Cultures: The Hofstede Model in Context. Online Readingsin Psycology and Culture, 2(1), 1-7

21. Cameron, K.S., Quinn, R.E. (2011). Diagnosing and Changing Organizational Culture: Based on the Competing Values Framework. 3rd ed. New Jersey: John Wiley \& Sons 